\title{
FOSTERING LANGUAGE LEARNER AUTONOMY: INDONESIAN EFL LECTURERS' VOICES
}

\author{
Endang Darsih \\ Department of English Education, Faculty of Teacher Training and Education, Universitas Kuningan, \\ Indonesia \\ Email: endangdarsih@gmail.com
}

APA Citation: Darsih, E. (2018). Fostering language learner autonomy: Indonesian EFL lecturers' voices. English Review: Journal of English Education, 7(1), 51-60. doi: 10.25134/erjee.v7i1.1495.

Published: 01-12-2018

\begin{abstract}
Studies reported that education in Indonesia has not been promoting learner autonomy as the main goal of the learning process. In fact, it could be one of the solutions to improve the quality of Indonesian students and a key goal for tertiary English learning. This explorative study was conducted to find out lecturer's beliefs about learner autonomy and the activities done by the lecturers to foster learner autonomy. Seventeen lecturers from English Education Study Program were voluntarily investigated and interviewed. Questionnaires about Teachers' Beliefs about Learner Autonomy compiled by Borg and Al-Busaidi (2012) were also employed in this study. The study revealed that majority of students were assessed to be not autonomous yet and there were various efforts and activities done by the lecturers to improve learner autonomy, such as providing a project based assignment, recommending a specific web and English mobile applications to assist their learning, keep motivating the students, fostering reading habit, involving students to select materials, and applying various teaching methodology.

Keywords: learner autonomy; teacher's beliefs; fostering learner autonomy; EFL; tertiary education.
\end{abstract}

\section{INTRODUCTION}

Autonomous learning is considered the pedestal of individuals' self-study, whereby, the individuals are largely responsible for their learning (Holec, 1981) as cited in Halil (2018) and learner autonomy has become a central ability to develop for a fruitful language learning/teaching process in EFL classes. However, based on researcher's observation in the teaching and learning process, it can be said that the context of higher education in Indonesia has not been too promoting learner autonomy as the main goal of the learning process. Moreover, some education practitioners have not been too familiar with the term "learner autonomy". In fact, as Lengkanawati (2014) said that learner autonomy is a vital factor in creating effective learning. Practice in the field shows that students have not shown high level of learning autonomy. This can be seen from students who tend to learn just before the exam or when the lecturer asks them to do so. Besides, there were always excuses from university students to postpone the assignments. The absence of strong awareness from within the students about the importance of learner autonomy becomes the common problem here so it is necessary once there is a paradigm shift that learning is not only a transfer of knowledge to the students, but also to provide space for students to explore the information and knowledge needed by themselves. Besides, low motivation of the students is also the serious problem that needs to be solved. Students tend to participate and involve passively in the classroom activities, only some students participating actively in the classroom activities, and some are not enthusiastic in interacting with the lecturer and other students.

Learner autonomy has become a trend for researchers in the last 10 years, but in 
Indonesia, the concept has yet to be thoroughly researched. There are several definitions of learner autonomy. Holec (1981) in Barilaro (2011) states that learner autonomy focuses on student involvement in their own learning process; namely in the determining of learning objectives, the content or materials, choosing the methods and techniques of learning, monitoring procedures of understanding and evaluating learning outcomes. In other words, learners are responsible in the learning process.

Learner autonomy has been the focus of teachers, educators, and researchers in various contexts (Balcikanli, 2010; Benson, 2012; Borg \& Al-Busaidi, 2012; Lengkanawati, 2014). It has an important role in improving student self-reliance so that it will give positive implications to the students in everyday life. If today the students still need help, he or she will become independent later on. As stated by Vygotsky (1934) in Barnard (2015) that "What the learner can do with help today, will be able to do independently tomorrow."

This concept also assumes that the independence of students in learning will affect the independence in life. It is in line with what Barnard (Benson, 2012) proposed that "Learner Autonomy means being independent in learning and life." In the same vein, Barnard (2015) said "the ultimate goal of learner autonomy is independence."

Moreover, Lengkanawati's study (2014) indicates that autonomy in learning has not been a common occurrence in the context of education in Indonesia, in contrast to the educational context in Australia that has applied learner autonomy in learning.

Since learner-centered approach is crucial in language learning, the endeavors to increase the learners' involvement in designing their language learning process should be prioritized (Yigit \& Yildirim, 2018). In this case, teacher or lecturer is the one who has substantial and important role in developing and fostering learner autonomy. A study conducted by Alonazi (2017) revealed that English language teachers often encouraged autonomous learners in their classrooms. They usually implemented different teaching strategies, which demonstrated the four roles: facilitator, counselor, resource and manager.

With reference to the importance of learner autonomy in creating successful English learning and the role of teacher in fostering learner autonomy, a few researchers focused on teachers' beliefs and practices regarding language learner autonomy in Asian context, such as in Vietman (Loi, in Barnard \& Li, 2016), in Philippines (Ranosa, in Barnard \& Li, 2016), in Thailand (Tapinta, in Barnard \& $\mathrm{Li}$, 2016), in Brunei Darussalam (Haji, et al., in Barnard \& Li, 2016) and in Indonesia (Lengkanawati, in Barnard \& Li, 2016). However, there have been limited studies concerned on the efforts done by University teachers in developing language learner autonomy. Therefore, this research intends not only to find out lecturers' beliefs about learner autonomy, but also efforts done to foster learner autonomy.

\section{METHOD}

This study was conducted by using a qualitative method, namely explorative research design. All lecturers at English Education study program, Faculty of Teacher Training and Education of Universitas Kuningan with the total number of 17 lecturers are regarded as the participants of this study. They are voluntarily involved in the present study.

In this study, data was collected by two means: questionnaire and interview. The questionnaire used in this study was adopted from a questionnaire about Teachers' Beliefs about Learner Autonomy compiled by Borg and Al-Busaidi (2012). The statement in the questionnaire is divided into four categories: technical, political, psychological and social. The measurement used Likert scale with five options, they are strongly disagree, disagree, unsure, agree, and strongly agree. The questionnaire was modified, translated as well as cross-checked by researcher, and then piloted with colleagues. Delivery was 
ENGLISH REVIEW: Journal of English Education Volume 7, Issue 1, December 2018

conducted in a bilingual version both online and through hard copies, which generated a total number of 17 respondents. All lecturers were asked to fill the questionnaires to find out their beliefs about learner autonomy, but not all lecturers were interviewed. The interview participants comprised eight teachers, who were selected from the questionnaire respondents who have expressed interest in further participation, with consideration of the years of teaching, gender and the type of students they taught. The interview was conducted in both English and Indonesian to get a better result. Results from questionnaires distributed to all lecturers of English Education study program were analyzed initially through Ms. Excel and using descriptive statistics to calculate frequency and percentage which would then be interpreted with data obtained from interviews.

\section{RESULTS AND DISCUSSION Profile of research participants}

Participants of the present study are all lecturers in English Education Study Program, Faculty of Teacher Training and Education in Universitas Kuningan with a total number of 17 lecturers. The lecturers of the English Education Study Program who are respondents have diversity in gender, the highest educational attainment, the teaching experience (ELT experience), and the experience at Language Center. These characteristics are presented in graphs below.

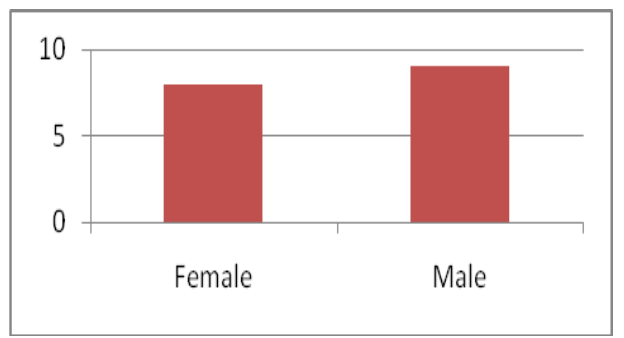

Figure 1. Profile of participants based on gender
p-ISSN 2301-7554, e-ISSN 2541-3643

https://journal.uniku.ac.id/index.php/ERJEE

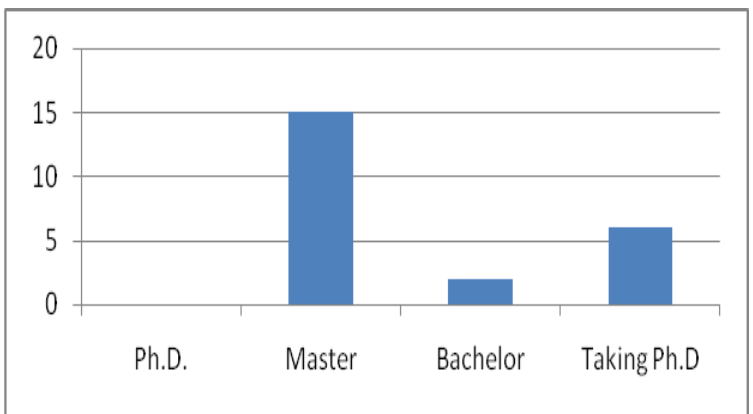

Figure 2. Profile of participants based on educational background

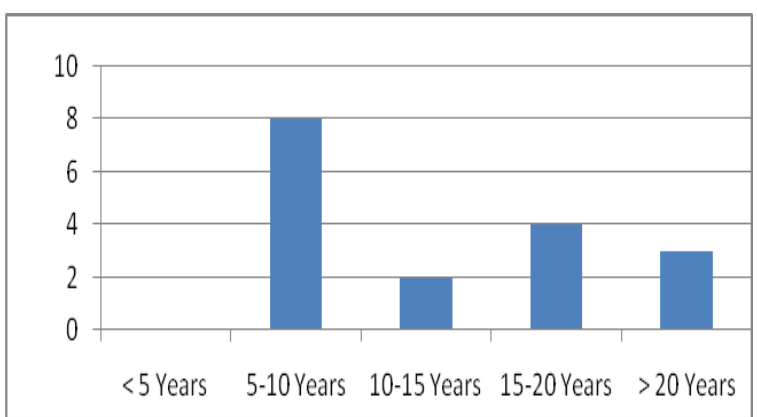

Figure 3. Profile of participants based on teaching experience

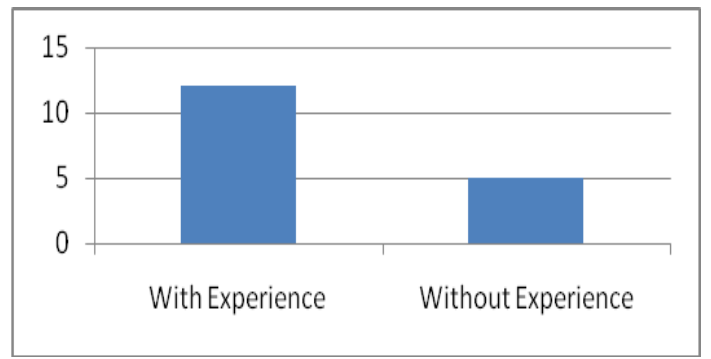

Figure 4. Profile of participants based on experience at language center

\section{Lecturers' beliefs about learner autonomy}

Based on the results of questionnaire data processing to 17 participants, it was obtained some items or statements in which almost the majority of participants agree (Agree/A) and strongly agree (Strongly Agree/SA) with statements number $3,4,7,11,12,25,28,29$, 35 and statement number 36 . The majority of participants $(88.2 \%)$ believe in some things. First, that student autonomy can be improved through routine activities where they perform individual tasks. Second, autonomy means that students can make choices about how they learn (82.4\%). Thirdly, the majority of participants $(64.7 \%)$ believe that involving students in determining materials or teaching materials 


\section{Endang Darsih}

Fostering language learner autonomy: Indonesian EFL lecturers' voices

can improve student autonomy. Fourth, $82.3 \%$ of participants believe that students who have a high level of confidence will have better autonomy of learning than the less confident. Fifth, the autonomy of learning makes students learn more effectively (70.6\%). Sixth, cooperative activities (co-operative group work activities) can help improve learner autonomy $(82.3 \%)$. The seventh, studentcentered learning is the ideal situation in improving learner autonomy $(82.3 \%)$. To eight, learning how to learn something is a key in improving learner autonomy (58.8\%). To the nine, teachers have a very important role in helping students improve their learning autonomy (76.5\%). Finally, the majority of participants $(82.4 \%)$ believe that learner autonomy has a positive influence on the success of language learning.

In the meantime, the questionnaire also shows that the majority of participants still doubt their beliefs about several things especially for items number $1,5,9,15,20$, 24 and item number 34 . The majority of participants doubt some things. First, students at all age can improve their learning autonomy. Second, students with low learning autonomy tend to be ineffective. Thirdly, the majority of participants doubt that it is difficult to improve learner autonomy with good language skills compared to those with less ability. Fourth, the autonomy of learning cannot be developed in lecturer-centered learning. Sixth, learning autonomy is only possible applied to adult students. The seventh, learner autonomy requires students to be totally independent of the lecturers. Finally, the participants' doubt can be seen from the statement that the students' skills do not affect their ability to improve their learning autonomy.

From the result of the questionnaire, it is also seen the belief of participants to some statements where the majority of respondents disagree (Disagree/D) and strongly disagree (Strongly Disagree/SD) such as on item statement number 8, 18 and item statement number 23. This disagreement seen in $76.5 \%$ of participants belief that student learning autonomy means learning without lecturer. Furthermore, the majority of participants (59\%) also disagree that learner autonomy does not develop without being assisted by lecturers. Finally, majority of participants (76.5\%) disagree and strongly disagree that student learning autonomy is a concept that is not suitable for non-western learners.

\section{Efforts in fostering learner autonomy}

Based on interviews with eight participants, it is revealed that the majority of participants concluded that the students of English Education study program are not fully autonomous; they are not fully independent, especially the first grade students due to the nature of his high school that is not independent and accustomed to the pattern of spoon-fed principle. Having analyzing the result of interview, it is revealed that there are several efforts or activities which are undertaken by lecturers in fostering learner autonomy in university, such as:

1. Providing a structured task (Project based or research based assignment) that should be done individually.

2. Recommending some specific internet, web or mobile applications as learning resources in accordance with the course.

3. Motivating the students to compete between campuses at various levels.

4. Growing and fostering reading habit for students by making chapter report or learning log at every meeting.

5. Applying various learning methods, such as Project Based Learning and Problem Based Learning to improve learner autonomy.

6. Involving the students to choose the material they will read according to their interest and ask them to write selfresponse for what they have learned and what results they will get from the reading.

7. Encouraging students to perform activities outside the campus, such as joining the debate club to improve the ability to speak and think critically. 
ENGLISH REVIEW: Journal of English Education Volume 7, Issue 1, December 2018

Based on data analysis, it can be concluded that the students of English Education study program are still not fully autonomous. There are several activities or efforts done by lecturers to foster learner autonomy. First, provide structured tasks (Project based or research based) that should be done individually and apply various learning methods, such as Project Based Learning and Problem Based Learning. This project based assignment is also proven by Loi (2017) that the students gained a higher degree of learner autonomy after participating in project work.

The following is statement taken from interview results:

"In my opinion, our students are still not autonomous. The efforts are like giving a structured task such as project that must be completed outside the class both individually and in group "- Lecturer 5

One of ways in measuring students' comprehension and ability is by providing tasks. Task provided to students must be proportional or in accordance with the ability of students, so that the task given does not become a burden for students. Providing structured tasks will make students become more active, trying to find a solution to the problem or tasks that he/she faces. By doing that, the student will be a hardworking person, never give up and students' thinking ability to find a way out of the problem will be increasing. Students who are active in completing their tasks will have a positive impact on students' affective, cognitive and psychomotor abilities. This is in line with what Benson proposed in Barnard \& Li (2016) that students can often contribute to the design of task and it can heighten their involvement in the classroom.

Besides, the next effort done by the lecturer in fostering learner is applying various teaching methods. One of the methods, namely Project Based Learning, is chosen because it is believed to improve students' higher order thinking skills and foster learner autonomy. It is also suggested
p-ISSN 2301-7554, e-ISSN 2541-3643

https://journal.uniku.ac.id/index.php/ERJEE

by the most national curriculum in Indonesia because it is expected to create studentcentered learning and enable the students to find the information by themselves. The following is statement taken from interview results:

"the efforts will vary, depends on the lecturers, I think our students have not been independent. Therefore, I apply the PBL (Project Based Learning) and Problem Based Learning method with the development of HOTS (Higher Order Thinking Skills) so they can become autonomous. In this way, they can be autonomous, because basically they are capable and have potential; they just need help and our role as a lecturer to develop it ". - Lecturer 4

Project Based Learning is a teaching method in which students can gain knowledge and skills by working for an extended period of time to investigate and respond to an authentic, engaging and complex question, problem, or challenge. Project Based Learning is believed to make classroom more engaging to students; a project engages their hearts and minds, and provides real-world relevance for learning. Project Based Learning also can improve students' learning. After completing a project, students understand content more deeply, remember what they learn and retain it longer than is often the case with traditional instruction. Because of this, students who gain content knowledge with this type of methods are able to apply what they know and can do to new situations.

If we review Indonesian Government Regulation number 65 year 2013 on process standards, then it is stated that the learning process must use a scientific approach by applying research-based learning (discovery or inquiry learning). To encourage learners to produce creative and contextual work, both individually and in groups, it is recommended to use a learning approach that produces project based learning and/or problem based learning tailored to the 


\section{Endang Darsih}

Fostering language learner autonomy: Indonesian EFL lecturers' voices

characteristics of competence and level of education. Based on the above statement, the expected learning is 'student-centered learning'. So that lecturers do not dominate the learning process. Asking the students to find out things for themselves rather than teaching them is very crucial as the basic strategy for student involvement in the classroom activities. It can also allow students to pursue their own interests (Benson, 2003) in Barnard and Li (2016). The students must acquire knowledge, attitudes, and skills, majorly by interacting among themselves and information. The students can get information from various sources, such as education facilities, media, and help from their tutors. Autonomous learning, therefore, enhances students to actively learn unlike the traditional mode of learning that promotes passive learning (Halil Küçükler, 2018).

The next effort done by the university teachers in fostering learner autonomy is to recommend the internet, specific web or English mobile applications as sources of learning in accordance with the course. As suggested by the latest curriculum in Indonesia that teachers are not the only source of learning. The Internet is a network of people and information, connected by telephone lines connected to a computer. Even more than 100.000 independent networks - public and private - are joining together to form this vast global communications system. In line with the widespread Internet access, the effort to integrate the Internet into English language teaching (ELT) and expand its various forms of use in teaching is also higher. This means that more teachers (lecturers or English instructors) and learners will use the Internet as a learning medium. The following is statement taken from interview results:

"In my opinion the English education program students are not autonomous. Moreover, I teach the first graders; most still want to be fed. Whatever the instructions should be very clear. Assigned tasks such as by depositing vocabulary, learning diary and following activities outside the classroom. I also recommend the web and mobile applications, such as oxford dictionary, hello English, etc. to learn English so that children can also learn outside of school hours. I release them to open gadgets or the internet, browse about the topic to be discussed. Besides, in this campus, free wifi can be a good solution for the students to download and install many free English mobile applications which are very beneficial for their learning and their achievements "Lecturer 3

Nowadays, technology is growing rapidly and as if the world is in the grip that is by accessing the internet via smartphone, even all people in this world including in Indonesia mostly have. This condition must become the chance for the students to use it for not only communication but also for learning. They can browse much information easily, whenever and wherever they want as smartphone is portable. Smartphone has become an idol and something very important until most students cannot be separated from the smartphone or mobile phone. This is an opportunity to take advantage of smartphones and android as a source and media that help the learning process. There are many free android and smartphone applications designed to assist students' learning and improve students' English skills, such as Oxpord Dictionary, Listen and Speak, Busuu, Cartoon Free English, Speak English Picture, Fluent English, English Podcast for Learners, Language Verb Trainer, PvP-Phrasal Verb, English Conversation Practice, Hello English, etc.

Motivating and supporting the students to compete between campuses at various levels is also an important effort to foster learner autonomy. The following is statement taken from interview results:

"In the classroom I teach, I think only a small part of students is autonomous, the 
ENGLISH REVIEW: Journal of English Education Volume 7, Issue 1, December 2018

syllabus is rarely read and they do not know what direction to learn on that day, far from preparing for themselves what they will learn that day, let alone the first graders who are still accustomed to be fed by teachers. To solve the problem, I usually provide tasks that will train them to become autonomous learners. For example, in the basic prosaic study class, I release students to choose literary works that they will read, make project literature response without any intervention of my own project and then presented in the class. I also assign students to write a chapter report for a syntax class and write self-response to what they have learned and what they can get ... "- Lecturer 1

All teachers and lecturers already know the importance of learning motivation for students. A strong motivation to learn will encourage students to want and try to learn earnestly. This makes sense and is reasonable. There are goals and desires that will be achieved by students through learning activities. Therefore, the learning activities that are run should not only meet the interests of teachers. The priority is the fulfillment of the wishes and needs of students in learning. This is in line with what Benson (2003) in Barnard and Li (2016) stated that supporting learners can foster autonomy in classroom.

The important role of motivation in the teaching and learning process needs to be understood by the lecturers so that they can perform various forms of action or assistance to the students. Motivation in learning is very important in the process of teaching and learning activities to improve the ability or learning outcomes. This is in accordance with the opinion of Wagman (2005) who said that motivation is one of factors that affects the ability of students in learning a foreign language.

Learning process will be successful when students have motivation to learn. Therefore, teachers need to cultivate students' learning motivation. To obtain
p-ISSN 2301-7554, e-ISSN 2541-3643

https://journal.uniku.ac.id/index.php/ERJEE

optimal learning outcomes, teachers are required to generate students' motivation to learn, so that effective student learning behavior will be formed. Several ways can be done to improve students' motivation to learn, such as clarifying goals to be achieved, creating a fun atmosphere in learning, generating students' interest in learning, giving feedback, reward and assessment to students' works, creating competition and cooperation among students.

Growing and fostering reading habit for students by making chapter report or learning log at each meeting is also believed to improve learner autonomy. The following is statement taken from interview result:

"I usually ask students to create a chapter report or learning log before the material begins. Therefore, they have a provision and certainly read in advance about the material to be delivered. In this way, they can actually learn on their own, and the class activity will talk more about what material they do not understand after reading and making chapter report" - Lecturer $2 \& 8$

From the result of interview above, it is found that teachers can also let the students to write about what they have learned, what they will do next or the direction of their learning. This way is believed to play an important role in heightening student involvement.

The last effort done by the lecturers in fostering learner autonomy is by giving freedom to the students to choose the material they will read according to their interest and write self-response for what they have learned and what results they will get from the reading. As we know that autonomy involves a willingness on the part of the learner to take responsibility for their own learning. Therefore students should be given a chance to define and select the materials and learning sources based on their interest. By using authentic materials and involving students to select the materials, this heightens involvement and personal 


\section{Endang Darsih}

Fostering language learner autonomy: Indonesian EFL lecturers' voices

relevance. The following is statement taken from interview result:

\begin{abstract}
"to improve learner autonomy, I ask them to choose and select reading material according to their own interests. For example, in reading for general purpose subject, students are asked to read the text of their choice and apply the reading strategy I teach to the text of their choice" - Lecturer 7
\end{abstract}

Autonomy need to be given to the students or learners so that they have the responsibility in organizing and disciplining themselves and in developing their own learning skills. These attitudes need to be possessed by students/learners because they are characteristic of the maturity of the learned person. In line with this, Moore (in Keegan, 1983) argues that the main feature of learner autonomy is the opportunity given to students or learners to participate in determining the objectives, sources, and evaluation of learning. Therefore, independent learning programs can be classified based on the size of the freedom (autonomy) given to students or learners to participate in determining the learning program.

Findings of this study have two important implications: 1) learner is the key of successful learning process in a learnercentered teaching, 2) lecturers' efforts as the optimization of students' learning. To begin with, in tertiary education level in which students centered teaching is emphasized, learner is the first one who is responsible so much for their learning. They are entrusted to determine what, how and why to learn. The more autonomous they are the bigger possibility they have to be more successful in learning. Majority of learning activities conducted in this university are centered on students, therefore learner autonomy is a crucial factor in creating effective and successful learning. Secondly, lecturers are the second ones who are responsible for maximizing students' learning experience and for fostering students' participation in different learning activities. Students and lecturers are inseparable determiners in effective teaching and learning process. There must be awareness from not only learner but also lecturer to complete each other. Learner centered teaching does not mean learning without teacher; again, there must be facilitator in assisting learners, improving learner autonomy and promoting learner autonomy in university is a desirable goal (Borg \& Alshumaimeri, 2017).

\section{CONCLUSION}

Learner autonomy plays a very important role in creating effective learning based on the most recent curriculum in Indonesia which centers on learner. Learner should be the one who do the messy works and the one who actively participate in the classroom activities. However, learner autonomy cannot be interpreted as learning without teachers. Teachers still become the second vital factor to make effective learnercentered classroom. In addition, Benson in Barnard and Li (2016) acknowledged that commitment of the teacher is the key to make a successful pedagogical task work.

Based on data analysis, two quite interesting findings have been revealed in this study especially regarding lecturers' beliefs about learner autonomy and efforts done to foster learner autonomy. The first finding is the majority of participants believe in some conceptions and aspects about learner autonomy. The second finding is efforts done by lecturers in improving learner autonomy vary based on the students needs, such as; 1) Providing a structured task (Project based or research based assignment) that should be done individually, 2) Recommending some specific internet or webs and English mobile applications to enhance their learning in accordance with the course; 3) Motivating and supporting students to compete between campuses at various levels; 4) Growing and fostering reading habit for students by making chapter report or learning $\log$ at each meeting; 4) Applying various learning methods, such as Project and Problem Based Learning to 
ENGLISH REVIEW: Journal of English Education Volume 7, Issue 1, December 2018

improve learner autonomy; 5) Involving students to select the material they will read according to their interests and write selfresponse for what they have learned and what results they will get from the reading; and 6) Encouraging students to perform activities outside the campus, for example joining the debate club to improve the ability to speak and think critically.

\section{REFERENCES}

Balcikanli, C. (2010). Learner autonomy in language learning: Student teachers' beliefs. Australian Journal of Teacher Education.

Barnard, R., \& Li, J. (2016). Language learner autonomy: Teachers' beliefs and practices in Asian contexts. Phnom Penh: Angkor Thom Printer Co, LTD.

Barnard, R. (2014). Learner sutonomy: A hand-out at two-day workshop at UPI Bandung, Indonesia.

Benson, P. (2012). Autonomy in language learning: Learning and life. A paper. Hong Kong Institute of Education.

Borg, S., \& Al-Busaidi, S (2012). Learner autonomy: English language teachers' beliefs and practices. ELT Reseach Paper. London, England.
p-ISSN 2301-7554, e-ISSN 2541-3643

https://journal.uniku.ac.id/index.php/ERJEE

Borg, S., \& Alshumaimeri, Y. (2017). Language learner autonomy in a tertiary context: Teachers' beliefs and practices. Language Teaching Research. doi:10.1177/1362168817725759.

Doğan, G., \& Mirici, İ. H. (2017). EFL instructors' perception and practices on learner autonomy in some Turkish universities. Journal of Language and Linguistic Studies, 13(1), 166-193.

Halil, K. (2018). Graduate students' proficiency strategy attitudes on autonomous learning in foreign language learning. English Language Teaching, 11(7)

Lengkanawati, N. S. (2014). Making EFL learners autonomous: Can language learning strategies help? Paper presented at 2014 ALAK International Conference on Applied Linguistics in the Era of Multiculturalism.

Loi, N. V. (2017). Promoting learner autonomy: Lesson from using project work as a supplement in English skills courses. Can Tho University Journal of Science, 7, 118-125.

Moore, S. (2011). The struggle to develop a "research culture" in a developing country. TESOL Quarterly. 
Endang Darsih

Fostering language learner autonomy: Indonesian EFL lecturers' voices 